\title{
Irfani
}

ISSN 1907-0969 E ISSN 2442-8272

Volume 15 Nomor 2 Desember 2019

Halaman 59-75

http://journal.iaingorontalo.ac.id/index.php/ir

\section{Strategi Kepemimpinan Kepala Madrasah dan Implikasi Terhadap Peningkatkan Mutu Pembelajaran di Madrasah Aliyah Negeri 1 Kota Gorontalo}

\author{
Nawir Lakisa ${ }^{1}$ Kasim Yahiji ${ }^{2}$ Said Subhan Posangi ${ }^{3}$ \\ Pascasarjana IAIN Sultan Amai Gorontalo \\ Email: nawirlakisa@gmail.com
}

\begin{abstract}
ABSTRAK
Artikel ini bertujuan untuk melihat strategi kepemimpinan Kepala Sekolah dalam Meningkatkan Mutu Pembelajaran Guru di Madrasah Aliyah Negeri 1 Kota Gorontalo, factor-faktor yang menjadi penghambat strategi kepemimpinan kepala sekolah dalam meningkatkan mutu pembelajaran guru di Madrasah Aliyah Negeri 1 Kota Gorontalo dan Solusi dari Kepala Madrasah Aliyah Negeri 1 Kota Gorontalo dalam Meningkatkan Mutu Pembelajaran Guru. Metode yang digunakan dalam penelitian ini adalah kualitatif dengan teknik pengumpulan data adalah dengan observasi, wawancara, dan dokumentasi. Hasil penelitian menunjukkan strategi kepala Madrasah dalam peningkatan mutu guru,yaitu: 1) Keadaan mutu guru yaitu jumlah guru keseluruhan 68 orang, berijazah S1 50 orang, S2 18 orang . guru yang PNS 52 orang, dan guru yang GTT 14 orang. Seтua guru membuat Silabus, RPP, penilai dan Jurnal. 2) Strategi Kepala Madrasah dalam peningkatan guru, a) Menyelenggarakan penataran (workshop) Madrasah. b) Memberi kesempatan kepada guru untuk meningkatkan pendidikannya. c) menyarankan guru agar melanjutkan ke S2. d) mningkatkan sikap profesionalisme guru. Yaitu kepala Madrasah menjalankan supervise untuk penilain guru setiap satu semester, dan e) menyarankan agar guru selalu rajin membaca, dan belajar, 3) kendala yang dihadapi kepala Madrasah dalam peningkatan mutu guru, antara lain: kemampuan teknologi guru yang kurang, kedisiplinan guru kurang jarak rumah dengan Madrasah jauh. (4) solusi yang diberikan oleh kepala Madrasah dalam peningkatan mutu guru yaitu menganjurkan guru agar kursus komputer, memberikan pembinaan, motivasi, ,dan saran agar guru berangkat lebih pagi dari rumahnya.
\end{abstract}

Kata Kunci: Strategi Kepala Madrasah, Mutu Guru

\section{PENDAHULUAN}

Salah satu persoalan pendidikan yang sedang dihadapi bangsa adalah persoalan mutu pendidikan pada suatu jenjang dan satuan pendidikan. Berbagai usaha telah dilakukan untuk meningkatkan mutu pendidikan nasional antara lain melalui berbagai pelatihan dan peningkatan kompetensi guru, pengadaan buku, dan alat pelajaran, perbaikan sarana dan prasarana pendidikan, dan meningkatkan mutu manajemen sekolah. Sekolah merupakan salah satu lembaga pendidikan 


\section{Irfani}

ISSN 1907-0969 E ISSN 2442-8272

Volume 15 Nomor 2 Desember 2019

Halaman 59-75

http://journal.iaingorontalo.ac.id/index.php/ir

yang dipercaya masyarakat dan negara untuk menyediakan sumber daya manusia yang dibutuhkan dalam perkembangan bangsa. untuk itu dibutuhkan seorang pemimpin yang didasarkan pada jati diri bangsa yang hakiki, bersumber nilai-nilai budaya dan agama serta mampu mengantisipasi perubahan yang terjadi di dunia pendidikan.

Kepemimpinan adalah suatu kekuatan yang penting dalam rangka pengelolaan. Oleh sebab itu kemampuan secara efektif merupakan kunci untuk menjadi seorang manajer yang efektif. Esensi kepemimpinan adalah kepengikutan (followership), yaitu kemauan orang lain atau bawahan untuk mengikuti keinginan pemimpin. Itulah ya ng menyebabkan seseorang menjadi pemimpin. Dengan kata lain, pemimpin tidak akan terbentuk apabila tidak ada bawahan. Jadi, kepala sekolah sebagai seorang pemimpin harus mampu: Mendorong timbulnya kemauan yang kuat dengan penuh semangat dan percaya diri para guru, staf dan sekolah dalam melaksanakan tugas masing-masing serta memberikan bimbingan dan mengarahkan para guru, staf dan para sekolah serta memberikan dorongan memacu dan berdiri di depan demi kemajuan dan memberikan inspirasi sekolah dalam mencapai tujuan.

Kepala sekolah sebagai pemimpin pendidikan harus dapat mengenal dan mengerti berbagai kedudukan, keadaan dan apa yang diinginkan baik oleh guru maupun oleh pegawai tata usaha serta pembantu lainya. Sehingga dengan kerja sama yang baik menghasilkan pikiran yang harmonis dalam usaha perbaikan sekolah. Kegagalan mencerminkan kurang berhasilnya perilaku serta peranan kepemimpinan seorang kepala sekolah. Semua ini perlu menjadi bahan timbangan bagi seorang kepala sekolah untuk menggerakkan seluruh anggota yang dipimpinnya.

Dengan demikian, keberhasilan suatu lembaga pendidikan sangat tergantung pada kepemimpinan Kepala Sekolah. Karena ia merupakan pemimpin di lembaganya, maka ia harus mampu membawa lembaganya kearah tercapainya tujuan yang telah di tetapkan, ia harus mampu melihat adanya perubahan serta mampu melihat masa depan dalam kehidupan global yang lebih baik. Kepala Sekolah harus bertanggungjawab atas kelancaran dan keberhasilan semua urusan pengaturan dan pengelolaan sekolah secara formal kepada atasannya atau secara informal kepada masyarakat yang telah menitipkan anak didiknya. Kepala Sekolah sebagai seorang pendidik, admdinistrator, pemimpin, dan supervisor, diharapkan dengan sendirinya yang lebih baik dan dapat menjanjikan masa depan.

\section{METODE PENELITIAN}

Penelitian ini merupakan jenis penelitian kualitatif dengan pendekatan leadership. Teknik pengumpulan data yaitu observasi, dokumentasi, dan wawancara. Kemudian data yang ada dianalisis dengan menggunakan teknik reduksi data, penyajian data dan penarikan kesimpulan.

${ }^{1}$ Aan Komari \& Cepi Triana, Visioneriy leadership Menuju Sekolah Efektif, (Jakarta: Bumi Aksara, 2006), h. 80 


\section{Irfani}

ISSN 1907-0969 E ISSN 2442-8272

Volume 15 Nomor 2 Desember 2019

Halaman 59-75

http://journal.iaingorontalo.ac.id/index.php/ir

\section{STRATEGI KEPEMIMPINAN KEPALA SEKOLAH}

Mutu pendidikan, sebagai pilar pengembangan sumber daya manusia yang sangat penting maknanya bagi kemajuan bangsa. Bahkan masa depan bangsa sering dikatakan terletak pada pendidikan yang berkualitas, sementara itu pendidikan berkualitas hanya terdapat pada lembaga pendidikan yang berkualitas pula. Karena itu upaya peningkatan mutu pendidikan dan mutu pembelajaran merupakan strategi agar terciptanya pendidikan yang berkualitas. Menurut Fattah dan Ali, strategi merupakan suatu seni menggunakan kecakapan dan sumber daya suatu organisasi untuk mencapai sasarannya melalui hubungannya yang efektif dengan lingkungan dalam kondisi yang paling menguntungkan. Jadi strategi merupakan kerangka dasar tempat suatu organisasi melanjutkan kehidupannya dengan penyesuaian-penyesuaian dengan lingkungannya. ${ }^{2}$

Kemudian Mulyasa, menekankan bahwa rencana yang dibuat harus menggambarkan aspek-aspek mutu proses yang ingin dicapai, kegiatan yang dilakukan, siapa yang harus melaksanakan, kapan dan dimana dilaksanakan, serta biaya yang diperlukan. ${ }^{3}$ Hal itu dapat dilakukan untuk mempermudah pihak sekolah dalam memperoleh dukungan moril dan financial dari masyarakat sekolah maupun masyarakat luar untuk meningkatkan mutu pendidikan dan kualitas pembelajaran di dalam institusi pendidikan. Selanjutnya Glucck mendefinisikan Strategi adalah satu kesatuan rencana yang komperehensif dan terpadu yang menghubungkan kekuatan strategi organisasi dengan lingkungan yang dihadapinya, kesemuanya menjamin agar tujuan organisasinya tercapai.

Sedangkan Lashway mendefinisikan Strategi ialah pola perilaku yang dirancang untuk mencapai kerjasama dan para anggota dalam mencapai tujuan organisasi. ${ }^{4}$ Lalu Dirawat mendeskripsikan kepemimpinan adalah kemampuan dan kesiapan yang dimiliki oleh seseorang untuk dapat mempengaruhi, mendorong, mengajak, menuntun, menggerakkan dan kalau perlu memaksa orang lain agar ia menereima pengaruh untuk selanjutnya berbuat sesuatu yang dapat membantu pencapaian sesuatu maksud dan tujuan. ${ }^{5}$

Dari pengertian di atas, dapat disimpulkan bahwa strategi merupakan wadah organisasi untuk melaksanakan kegiatan. Dalam meningkatkan mutu, dibutuhkan peran penting anggota organisasi guna menghubungkan satu kesatuan rencana dan kerjasama untuk mencapai tujuan yang telah ditetapkan. Berdasarkan

\footnotetext{
${ }^{2}$ Usuf Hadijaya, Menyusun Strategi Berbuah Kinerja Pendidik Efektif, (Medan: Perdana Publishing, , 2013),h. 11

${ }^{3}$ bid, hal. 12

${ }^{4}$ Eti Rochaety, dkk, (Sistem Informasi Manajemen, Jakarta: Bumi Aksara, 2010) ,h. 27

5 Syafaruddin dan Asrul, (Kepemimpinan Pendidikan Kontemporer, Bandung: Citapustaka Media, 2015),h. 146
} 


\section{Irfani}

ISSN 1907-0969 E ISSN 2442-8272

Volume 15 Nomor 2 Desember 2019

Halaman 59-75

http://journal.iaingorontalo.ac.id/index.php/ir

pengertian di atas dapat disimpulkan bahwa strategi pemimpin sangat berpengaruh pada bawahannya untuk mencapai tujuan organisasi atau lembaga pendidikan. Artinya tugas Kepala Sekolah dipengaruhi oleh strategi apa yang dia terapkan dalam kepemimpinan, sebab kepemimpinan yang efektif selalu memanfaatkan kerja sama dengan para bawahan untuk mencapai tujuan organisasi. ${ }^{6}$

\section{BENTUK STRATEGI KEPEMIMPINAN KEPALA SEKOLAH}

Kepala sekolah sebagai pemimpin pendidikan yang berada di sekolah memiliki peran yang sangat penting dalam memperoleh kualitas pembelajaran yang baik. Tujuan tersebut dapat diperoleh apabila kepala sekolah mampu menciptakan strategi yang relevan untuk meningkatkan kualitas pembelajaran. Strategi adalah serangkaian keputusan dan tindakan mendasar yang dibuat oleh manajemen puncak dan diimplementasikan oleh seluruh jajaran dalam suatu organisasi dalam rangka mencapai tujuan organisasi. ${ }^{7}$ Strategi merupakan sejumlah keputusan dan aksi yang ditunjukkan untuk mencapai tujuan (goal) dalam menyesuaikan sumber daya organisasi dengan peluang dan tantangan yang dihadapi dalam lingkungan industrinya. ${ }^{8}$

Seorang Kepala Sekolah adalah pimpinan pengajaran. Tugasnya adalah melaksanakan dan mengawasi aktivitas sekolah dengan menyusun tujuan, memelihara disiplin dan mengevaluasi hasil pembelajaran dan pengajaran yang dicapai. Pada saat ini kepala sekolah didorong untuk menjadi pemimpin yang memudahkan personil sekolah dengan membangun kerjasama, menciptakan jaringan kerja dan mengatur semua komponen dengan komunikasi yang baik. Ada sebagian pendapat menyebutkan bahwa hal tersebut adalah gaya kepemimpinan. Gaya kepemimpinan ada tiga, yaitu : karismatik, transaksional dan transformasional. ${ }^{9}$

Sebagian ahli menggunakan istilah strategi kepemimpinan. Intinya adalah pilihan terhadap pemikiran dan perilaku kepala sekolah dalam mempengaruhi staf, para guru, personil dan murid-murid sekolahnya. Saat ini kepala sekolah memiliki sekurang-kurangnya tiga strategi luas, yaitu : hirarkial, transformasional dan fasilitatif. Setiap strategi memiliki keuntungan penting dan memiliki keterbatasan.

6 Marno \& Triyo Supriyanto, (Manajemen dan Kepemimpinan Pendidikan Islam, Bandung: PT Refika Aditama, 2008),h. 30

${ }^{7}$ Sondang P. Siagian, (Manjemen Strategi, Jakarta: Bumi Aksara, 2004),h. 20.

${ }^{8}$ Mudrajad Kuncoro, (Strategi Bagaimana Meraih Keunggulan Kompetitif, Jakarta: Erlangga, 2016),h. 12.

${ }^{9}$ Syafaruddin dan Asrul, (Kepemimpinan Pendidikan Kontemporer, Bandung: Citapustaka Media, 2013),h. 145. 


\section{Irfani}

ISSN 1907-0969 E ISSN 2442-8272

Volume 15 Nomor 2 Desember 2019

Halaman 59-75

http://journal.iaingorontalo.ac.id/index.php/ir

\section{1) Strategi Hirarki}

Strategi hirarki memberikan cara pandang luas, cara penerimaan luas dalam mengelola organisasi, menyampaikan janji efisiensi, pengawasan dan rutinitas yang direncanakan. Bagaimanapun strategi hirarki cenderung untuk mrnghambat kreativitas dan komitmen, mengembalikan hubungan pegawai sekolah ke dalam suatu keteraturan yang ketat.

2) Strategi Transformasional

Strategi transformasional memiliki kapasitas untuk memotivasi dan memberikan informasi kepada anggota. Khususnya bila organisasi menghadapi dan melakukan perubahan utama. Mereka memberikan suatu pengertian akan tujuan dan makna bahwa pimpinan dapat menyatukan personilnya dalam suatu tindakan bersama untuk kemajuan. Di sisi lain strategi transformasional sukar, karena itu sejak awal mereka memerlukan pengembangan keterampilan intelektual yang tinggi.

3) Strategi Fasilitatif

Strategi fasilitatif sebagai suatu perilaku yang menggunakan kemampuan kebersamaan dari sekolah untuk beradaptasi, memecahkan masalah dan peningkatan kinerja. Tindakan kepala sekolah yang menggunakan strategi fasilitatif bila mereka menangani hambatan sumber daya, membangun tim kerja memberikan umpan balik, koordinasi, manajemen konflik, menciptakan jaringan komunikasi melaksanakan kerjasama politik dan sebagai model dalam visi sekolah. Strategi fasilitatif menciptakan suatu peran baru kepemiminan untuk memudahkan pegawai dalam menjalankan pekerjaannya, terutama melalui hubungan kerjasama baik. Fasilitatif mengambil waktu untuk mencapai kepuasan kerja administratif dan menciptakan sumber daya yang ada. $^{10}$

\section{MENINGKATKAN KUALITAS PEMBELAJARAN}

Peningkatan kualitas di dalam sekolah akan terlaksana apabila didukung oleh sumber daya manusia (SDM) yang memiliki kemampuan, integritas dan kemampuan yang tinggi, karena kalau kalau tidak, mutu sekolah hanya akan menjadi eforia semata. Salah satu faktor kunci keberhasilan untuk meningkatkan kualitas pembelajaran harus didasari oleh kemampuan konsep, teknis dan manusiawi.

Manajemen pendidikan di sekolah adalah proses aplikasi fungsi manajemen dalam melaksanakan proses pengajaran dan pembelajaran untuk mencapai tujuan pendidikan. Untuk mencapai tujuan pendidikan di sekolah, peranan kepala sekolah dalam menjalankan manajemen pendidikan sangat menentukan pencapaian tujuan dengan dukungan sumber daya personel, materi,

\footnotetext{
${ }^{10}$ Ibid, hal. 146-149.
} 


\section{Irfani}

ISSN 1907-0969 E ISSN 2442-8272

Volume 15 Nomor 2 Desember 2019

Halaman 59-75

http://journal.iaingorontalo.ac.id/index.php/ir

financial dan lingkungan masyarakat. ${ }^{11}$

Sekolah merupakan salah satu objek yang terlibat dalam kegiatan pembelajaran di sekolah. Dalam kegiatan tersebut, sekolah mengalami tindak mengajar dan merespons dengan tindak belajar. Pada umumnya, semula sekolah menyadari pentingnya belajar. Berkat informasi guru tentang sasaran belajar, maka sekolah mengetahui apa arti bahan belajar baginya dan sekolah mengalami suatu proses belajar. Pendidikan dapat dikatakan baik apabila pendidikan itu dapat memberi kesempatan berkembangnya semua aspek pribadi manusia atau dengan kata lain rumusan tujuan tersebut berisikan pengembangan aspek manusia. Agar dapat melakukan kegiatan idealitas kepemimpinan kepala Sekolah untuk meningkatkan kualitas pembelajaran, menurut Mulyasa harus memperhatikan dan menerapkan prinsip-prinsip berikut ini:

a. Bersikap terbuka, tidak memaksakan kehendak, tetapi bertindak sebagai fasilitator yang mendorong suasana demokratis gur dan kekeluargaan

b. Mendorong guru mau dan mampu mengemukakan pendapat-pendapatnya dalam memecahkan suatu masalah, dapat mendorong aktivitas dan kreativitas guru

c. Mengembangkan kebiasaan untuk berdiskusi secara terbuka, dan mendidik gru untuk mau mendengarkan pendapat orang lain secara objektif (hal demikian dapat dilakukan dengan jalan menengahi pembicaraan dan menterjemahkan pembicaraan orang lain untuk dapat dipahami

d. Mendorong para guru dan pegawai lainnya untuk mengambil keputusan yang paling baik dan mentaati keputusan itu, dan berlak sebagai pengarah, pengatr pembicaraan, perantara, dan pengambil kesimpulan secara redaksional.

\section{HASIL PENELITIAN}

Strategi Kepemimpinan Kepala Madrasah Aliyah Negeri 1 Kota Gorontalo dalam Peningkatkan Mutu Guru

Adapun data yang diperoleh dari obeservasi melalui wawancara dengan Kepala Madrasah Aliyah Negeri 1 Kota Gorontalo bahwa pendidikan guru Madrasah Aliyah Negeri 1 Kota Gorontalo sudah memenuhi kualifikasi, karena dari 68 jumlah guru, yang S1 50 orang sesuai dengan mata pelajaran masingmasing dalam mengajarnya, dan yang S2 18 orang. Sebagian guru sudah mempunyai laptop dan dapat mengoperasikannya. Sebelum melaksanakan proses belajar mengajar, guru Madrasah Aliyah Negeri 1 Kota Gorontalo telah menyiapkan segala kebutuhan sebelum pembelajaran dimulai membuat RPP,

\footnotetext{
${ }^{11}$ Sudaryono, Dasar-Dasar Evaluasi Pembelajaran, (Yogyakarta: Graha Ilmu, 2012),h.
} 57. 


\section{Irfani}

ISSN 1907-0969 E ISSN 2442-8272

Volume 15 Nomor 2 Desember 2019

Halaman 59-75

http://journal.iaingorontalo.ac.id/index.php/ir

Penilaian maupun jurnal. ${ }^{12}$ Hal lain yang dilakukan guru di Madrasah Aliyah Negeri 1 Kota Gorontalo, selain menjalankan tugasnya sebagai seorang pendidik adalah sebagai orang tua kedua, dan menempatkan diri di masyarakat karena tugas seorang guru, yaitu (1) bidang profesi yang meliputi mendidik, mengajar,dan melatih, (2) bidang kemanusiaan, guru harus mampu menempatkan diri sebagai orangtua kedua, (3) bidang masyarakat, masyarakat menempatkan pada tempat yang lebih terhormat dilingkungannya karena dari seorang guru mereka berharap mendapatkan ilmu pengetahuan.

Selain itu Kepala Madrasah Aliyah Negeri 1 Kota Gorontalo mengharapkan guru sebagai pengajar di Madrasah Aliyah Negeri 1 Kota Gorontalo memiliki tanggung jawab moral yang tinggi, memiliki komitmen terhadap visi, misi, dan tujuan pendidikan. Adapun memiliki tanggung jawab moral yang tinggi, memiliki komitmen terhadap visi, misi, dan tujuan pendidikan, yaitu (1) guru membuat Silabus, RPP, Jurnal, dan kebutuhan sebelum proses belajar mengajar, (2) dalam proses belajar mengajar guru sudah mengikuti standar pendidikan yang saat ini digunakan, yaitu kurikulum tingkat satuan pendidikan (KTSP) dan Kurikulum 2013, (3) guru disiplin dalam menjalankan tugasnya sebagai pendidik, walaupun belum $100 \%$. (4) guru juga memberikan peningkatkan mutu kepada peserta didiknya untuk belajar lebih giat. ${ }^{13}$

Menurut Meykie Daud, M.Pd selaku wakamad bidang keagamaan dan keasramaan, dalam peningkatan mutu guru, kepala madrasah bertindak sebagai motivator Supervisor dan pelaksana program yang telah direncanakannya. Pelaksanaanya motivasi ketika rapat atau pada waktu yang memang diperlukan untuk memberi pembinaan. ${ }^{14}$ Terdapat beberapa prinsip yang dapat diterapkan kepala madrasah untuk mendorong tenaga kependidikan agar mau dan mampu meningkatkan profesionalismenya. prinsip-prinsip tersebut adalah:

a. Para tenaga kependidikan akan bekerja lebih giat apabila kegiatan yang dilakukan menarik, dan menyenangkan.

b. Tujuan kegiatan perlu disusun dengan jelas dan diinformasikan dengan para tenaga kependidikan sehingga mereka mengetahui tujuan dia bekerja.

c. Para tenaga kependidikan juga dapat dilibatkan dalam menyusun tujuan tersebut.

d. Para tenaga kependidikan harus selalu diberitahu tentang hasil dari setiap pekerjaannya.

${ }^{12}$ Hasil Obervasi Tentang Kualifikasi Pendidikan Guru di Madrasah Aliyah Negeri 1 Kota Gorontalo pada tanggal 14 November 2019

${ }^{13}$ hasil observasi tentang tugas dan tanggung jawab guru pada tanggal 14 November 2019

14 Meykie Daud, M.Pd Wakamad Bidang Keagamaan dan Keasramaan Madrasah Aliyah Negeri 1 Kota Gorontalo pada tanggal 14 November 2019 


\section{Irfani}

ISSN 1907-0969 E ISSN 2442-8272

Volume 15 Nomor 2 Desember 2019

Halaman 59-75

http://journal.iaingorontalo.ac.id/index.php/ir

e. Pemberian hadiah lebih baik dari pada hukuman, namun sewaktu-waktu hukuman juga diperlukan.

f. Usahakan untuk memenuhi kebutuhan tenaga kependidikan dengan jalan memperhatikan kondisi fisiknya, memberikan rasaaman, menunjukkan bahwa kepala madrasah memperhatika mereka, mengatur pengalaman sedemikian rupa sehingga setiap pegawai pernah memperoleh kepuasan dan penghargaan.

Selain prinsip-prinsip untuk meningkatkan profesionalisme guru di Madrasah Aliyah Negeri 1 Kota Gorontalo, sesuai dengan buku program madrasah, Kepala Madrasah Aliyah Negeri 1 Kota Gorontalo, menyebutkan strategi dalam peningkatan mutu, yaitu sebagai berikut:

a) Menyelenggarakan penataran (workshop) madrasah

b) Memberi kesempatan kepada guru untuk meningkatkan pendidikannya, dengan melanjutkan ke S2

c) Meningkatkan sikap profesionalisme guru dengan selalu rajin membaca, belajar dan berdiskusi dengan guru-guru yang lain sesuai mata pelajaran masing-masing.

Berdasarkan paparan di atas berikut ini hasil wawancara dengan Kepala Madrasah Aliyah Negeri 1 Kota Gorontalo tentang penggunaan bentuk-bentuk strategi dalam meningkatkan kualitas pembelajaran, yakni sebagai berikut.

Ya.Saya menggunakan strategi untuk meningkatkan kualitas pembelajaran, strategi tersebut disusun mulai dari perencanaan sampai dengan penetapan. tujuan strategi yaitu meningkatnya kualitas pembelajaran di madrasah ini. Waktu saya untuk menetapkan strategi yang telah dirancang adalah setiap hari namun setiap pergantian semester saya biasanya mengubah strategi jika dirasa strategi tersebut sudah berhasil dan sudah benar-benar diterapkan oleh guru, staf tata usaha. Target utama untuk strategi yang diterapkan adalah guru terutama guru mata pelajaran karena guru yang berhadapan langsung dengan peserta didik untuk proses meningkatkan hasil belajar. $^{15}$

Strategi yang saya gunakan dalam meningkatkan kualitas pembelajaran ialah dengan strategi fasilitatif yang artinya sebagai suatu perilaku yang menggunakan kemampuan kebersamaan dari sekolah untuk berdaptasi, memecahkan masalah dan peningkatan kinerja. Saya

${ }^{15}$ Dr. H. Waris Masuara, S. Ag, M.H.I Kepala Madrasah Aliyah Negeri 1 Kota Gorontalo, wawancara, Tanggal 15 November 2019 


\section{Irfani}

ISSN 1907-0969 E ISSN 2442-8272

Volume 15 Nomor 2 Desember 2019

Halaman 59-75

http://journal.iaingorontalo.ac.id/index.php/ir

menggunakan strategi fasilitatif karena madrasah kami banyak menghadapi hambatan terutama dalam bidang sumber daya. Strategi digunakan setiap hari sampai tercapainya tujuan yang telah ditetapkan dan strategi diterapkan melalui musyawarah kepada para guru terlebih dahulu. Bentuk strategi yang telah dirancang dan Insya Allah akan terlaksana setiap hari. Saya menerapkan bahwasanya guru harus kreatif dalam penggunaan atau pembuatan media pembelajaran karena sarana dan prasarana di madrasah ini masih terbilang kurang memadai. Program yang saya rancang tersebut mengajarkan peserta didik agar selalu ingat kepada Allah dan agar selalu melaksanakan kewajibannya dan kepada guru agar lebih aktif dan kreatif. Kemudian guru tidak saya izinkan menggunakan handphone pada saat mengajar karena akan menimbulkan dampak kepada peserta didik dan profesional kerja dan Alhamdulillah strategi tersebut dapat meningkatkan kualitas pembelajaran. ${ }^{16}$

Hasil wawancara dengan Wakil Kepala Madrasah bagian SDM dan Hubmas mengenai bentuk strategi yang diterapkan Kepala Madrasah dalam meningkatkan kualitas pembelajaran, beliau menjelaskan sebagai berikut:

Strategi yang dilakukan oleh Kepala Madrasah ialah dengan strategi fasilitatif yaitu dengan cara selalu berkomunikasi kepada kami para guru serta mengadakan rapat atau musyawarah setiap bulan untuk mendapat saran, ide, gagasan dan masukan dari guru maupun pegawai yang ada di madrasah ini. Dengan begitu kepala madrasah mendapat keputusan terbaik untuk melaksanakan strategi yang telah dirancang dan dapat mencapai tujuan yang telah ditetapkan. Bentuk strategi yang dilakukan Kepala Madrasah untuk meningkatkan kualitas pembelajaran adalah strategi yang menerapkan kepada guru, kepala sekolah menerapkan program media pembelajaran yang kreatif terkait sarana dan prasarana di madrasah ini kurang memadai. Kami juga tidak diizinkan oleh kepala madrasah menggunakan handphone pada saat mengajar. Saya sangat setuju dengan strategi tersebut dan Alhamdulillah strategi tersebut dapat meningkatkan kualitas pembelajaran di madrasah ini. ${ }^{17}$

Selain melakukan wawancara dengan Kepala Madrasah dan Wakil Kepala Madrasah, peneliti juga wawancarai salah satu guru yang menjadi pembina sendratasik di Madrasah Aliyah Negeri 1 Kota Gorontalo mengenai strategi kepemimpinan yang diterapkan kepala madrasah dalam meningkatkan kualitas pembelajaran.

16 Dr. H. Waris Masuara, S. Ag, M.H.I Kepala Madrasah Aliyah Negeri 1 Kota Gorontalo, wawancara, Tanggal 15 November 2019

17 Maria Y. Ahmad, M.Pd, Wakil Kepala Madrasah bagian SDM dan Hubmas, wawancara, Tanggal 17 November 2019 


\section{Irfani}

ISSN 1907-0969 E ISSN 2442-8272

Volume 15 Nomor 2 Desember 2019

Halaman 59-75

http://journal.iaingorontalo.ac.id/index.php/ir

Ya. Sepengetahuan saya Kepala Madrasah menggunakan strategi untuk meningkatkan kualitas pembelajaran. Strategi juga diterapkan setiap hari namun biasanya setiap pergantian semester kepala madrasah mengubah strateginya jika strategi tersebut dirasa sudah mencapai tujuan dan para guru, staf tata usaha beserta siswa sudah benar-benar menerapkan bentukbentuk strategi yang telah ditetapkan. Cara kepala madrasah menerapkan strategi awalnya musyawarah terlebih dahulu kepada sumber organisasi apakah strategi tersebut memberatkan atau tidak. Target utama strategi tersebut adalah para guru mata pelajaran karena guru yang berkomunikasi langsung dengan pesta didik dalam proses belajar mengajar, serta waktu yang dibutuhkan yaitu sampai strategi benar-benar sudah mencapai tujuan. $^{18}$

Sama halnya dengan yang dijelaskan oleh pembina sendratasik di Madrasah Aliyah Negeri 1 Kota Gorontalo, Yasin Bano, S.Pd selaku wakamad bidang kurikulum juga menambahkan mengenai strategi kepemimpinan yang diterapkan kepala madrasah dalam meningkatkan kualitas pembelajaran.

Strategi yang digunakan oleh kepala madrasah dalam meningkatkan kualitas pembelajaran ialah dengan cara beradaptasi serta menjalin komunikasi dengan baik terhadap guru, pegawai maupun siswa. Kepala madrasah juga selalu memudahkan para guru dalam menjalankan pekerjaannya dengan cara menjalin hubungan kerjasama dengan baik maupun bermusyawarah. Bentuk strategi yang dilaksanakan kepala madrasah untuk meningkatkan kualitas pembelajaran adalah membantu serta memotivasi guru, kepala madrasah menerapkan program media pembelajaran yang kreatif. Kepala madrasah tidak pernah membedakan apapun terkait usaha yang dilakukan untuk proses meningkatkan kualitas madrasah, kalau soal handphone saya tidak dilarang namun tetap harus professional dalam bekerjadan Alhamdulillah strategi tersebut dapat meningkatkan kualitas pembelajaran ${ }^{19}$

Dalam penelitian ini, peneliti juga mewawancarai staf tata usaha Madrasah Aliyah Negeri 1 Kota Gorontalo, yakni sebagai berikut:

Ya. Kepala madrasah menggunakan strategi, strategi tersebut tidak hanya diperuntukkan kepada pada guru mata pelajaran saja tapi juga kepada staf untuk lebih profesional dalam melaksanakan tanggungjawab. Biasanya

\footnotetext{
November 2019

${ }^{18}$ Amran Ismail, S.Pd, M.A sebagai guru pembina sendratasik, wawancara, Tanggal 16

19 Yasin Bano, S.Pd selaku wakamad bidang kurikulum wawancara, Tanggal 16 November 2019
} 


\section{Irfani}

ISSN 1907-0969 E ISSN 2442-8272

Volume 15 Nomor 2 Desember 2019

Halaman 59-75

http://journal.iaingorontalo.ac.id/index.php/ir

kepala madrasah mengubah strateginya jika strategi sudah benar-benar berhasil dan mencapai tujuan ${ }^{20}$.

Berdasarkan hasil wawancara dengan Kepala Madrasah, Wakil Kepala Madrasah SDM dan Hubmas, Guru Pembina Sendratasik dan Staf Tata Usaha maka dapat disimpulkan bahwa Kepala Madrasah benar menggunakan strategi yang telah direncanakan terlebih dahulu untuk tercapainya tujuan utama yaitu meningkatnya kualitas pembelajaran di Madrasah Aliyah Negeri 1 Kota Gorontalo.

Selain itu menurut Dra. Warni Biya selaku keuangan dan kesetaraan pegawai dan karyawan, Kepala Madrasah menjalankan bentuk strategi kepada para guru menggunakan strategi kreatif dalam hal pembuatan media pembelajaran karena sarana dan prasarana di dalam madrasah tersebut memang kurang memadai. Dengan adanya strategi tersebut, guru lebih terampil dan bisa meningkatkan mutu dalam hal pembuatan media pembelajaran sehingga membantu peserta didik lebih belajar lebih aktif.$^{21}$

Meningkatkan mutu sangat diperlukan oleh guru agar semangat dalam menjalankan tugasnnya mereka akan merasa diperhatikan oleh Kepala Madrasah. Dengan itu guru akan senantiasa memperbaiki kekurangan dalam pembelajarannya. Hal ini dikuatkan oleh Kepala di Madrasah Aliyah Negeri 1 Kota Gorontalo Bapak Dr. H. Waris Masuara, S.Ag, M.H.I dalam wawancara beliau pada tanngal 15 November 2019.

Peningkatkan mutu saya terapkan dalam mengatur lingkungan kerja, suasana kerja, maupun menerapkan prinsip penghargaan dan hukuman. Penghargaan yang saya berikan tidak berupa materi, tetapi berupa pujian. Saya selalu mendorong para guru agar meningkatkan kinerjannya, kami juga bersamasama mencari solusi jikalau sampai ada permasalahan, dengan meningkatkan perhatian kepada guru agar tidak merasa diabaikan dan lebih merasa dihargai jerih payahnnya. ${ }^{22}$

Berdasarkan hasil wawancara dengan Kepala di Madrasah Aliyah Negeri 1 Kota Gorontalo Bapak Dr. H. Waris Masuara, S.Ag, M.H.I, Siti Nurain Aripin S.Pd selaku analisis prestasi peserta didik dan MGMP juga menegaskan bahwa:

Meskipun terkadang rasa lelah dan pesimis sering terjadi. Tapi hal tersebut tidak jadi hambatan. Selama ini belum pernah ada hambatan dalam

\footnotetext{
${ }^{20}$ Rofiq S. Adam, sebagai pengelola Web, wawancara, Tanggal 16 November 2019

${ }^{21}$ Dra. Warni Biya Keuangan Dan Kesetaraan Pegawai Dan Karyawan, wawancara, Tanggal 16 November 2019

${ }^{22}$ Dr. H. Waris Masuara, S. Ag, M.H.I Kepala Madrasah Aliyah Negeri 1 Kota Gorontalo, wawancara, Tanggal 15 November 2019
} 


\section{Irfani}

ISSN 1907-0969 E ISSN 2442-8272

Volume 15 Nomor 2 Desember 2019

Halaman 59-75

http://journal.iaingorontalo.ac.id/index.php/ir

meningkatkan mutu, kalaupun nanti ada hambatan akan dicarikan solusinya. $^{23}$

Dorongan dan penghargaan merupakan dua sumber efektif diterapkan oleh kepala Madrasah untuk meningkatkan mutu guru. Mutu seorang guru dipengaruhi berbagai faktor dari dalam maupun dari lingkungan. Hal tersebut sudah dirasakan oleh guru-guru yang ada di Madrasah Aliyah Negeri 1 Kota Gorontalo Ibu Maria Y. Ahmad, M.Pd sebagai Wakil Kepala Madrasah bagian SDM dan Hubmas dan Amran Ismail, S.Pd, M.A sebagai guru pembina sendratasik, yaitu sebagai berikut.

Bapak Dr. H. Waris Masuara, S.Ag, M.H.I sering memberikan nasehat untuk meningkatkan mutu terhadap para guru. Biasanya setiap ada rapat beliau memberikan motivasi. Beliau memberikan nasehat-nasehat, arahan. Terkadang juga memuji untuk para guru yang berprestasi, dan mendorong untuk para guru yang lain lebih meningkatkan mutu dan kinerjanya demi kemajuan madrasah.

Setelah adanya program madrasah untuk meningkatkan mutu guru ,saya lebih giat,disiplin, dan bersemangat. Tidak hanya saya tapi juga temanteman guru yang lainya, hal itu bisa dilihat dalam keseharian di Madrasah Aliyah Negeri 1 Kota Gorontalo. ${ }^{24}$

Selain itu juga, Roni Tolinggi salah satu pegawai tata usaha dalam bidang infentarisir dan pengarsipan Madrasah Aliyah Negeri 1 Kota Gorontalo menambahkan mengenai peningkatan mutu yang diterapkan oleh kepala madrasah, yaitu sebagai berikut.

Kepala Madrasah selalu memberikan motivasi kepada setiap guru mata pelajaran agar lebih professional dalam melaksanakan tugas agar tujuan madrasah yang diinginkan tercapai proses belajar mengajar di Madrasah Aliyah Negeri 1 Kota Gorontalo selama ini berjalan dengan kondusif, disiplin, sesuai jadwal dan lancar. Walaupun ada guru yang tidak masuk atau terlambat pasti punya alasan yang kuat serta minta izin pada guru piket dan kepala Madrasah. ${ }^{25}$

Kepala Madrasah perlu memberi dorongan untuk meningkatkan profesionalisme tenaga kependidikan. Dengan adanya dorongan guru akan

\footnotetext{
${ }^{23}$ Siti Nurain Aripin S.Pd selaku analisis prestasi peserta didik dan MGMP Madrasah Aliyah Negeri 1 Kota Gorontalo, wawancara, Tanggal 15 November 2019

${ }^{24}$ Maria Y. Ahmad, M.Pd, Wakil Kepala Madrasah bagian SDM dan Hubmas, wawancara, Tanggal 17 November 2019

${ }^{25}$ Maria Roni Tolinggi bidang infentarisir dan pengarsipan Madrasah Aliyah Negeri 1 Kota Gorontalo wawancara, Tanggal 17 November 2019
} 


\section{Irfani}

ISSN 1907-0969 E ISSN 2442-8272

Volume 15 Nomor 2 Desember 2019

Halaman 59-75

http://journal.iaingorontalo.ac.id/index.php/ir

terangsang untuk meningkatkan mutunya. Semua tujuan kegiatan perlu disusun dengan jelas dan diinformasikan kepada para guru sehingga mereka mengetahuni tujuan bekerja. Para guru juga dilibatkan dalam menyusun tujuan tersebut. Hubungan yang harmonis juga sangatlah penting antara kepala madrasah dengan guru, hubungan kerja yang baik akan lebih memberikan rasa aman dalam melakukan sebuah pekerjaan maupun profesi. Oleh karna itu, keberhasilan dalam hal meningkatkan mutu sangatlah penting untuk meningkatkan kualitas guru itu sendiri.

Dalam hal ini Peneliti juga menanyakan kepada Ketua Komite Madrasah Aliyah Negeri 1 Kota Gorontalo, yaitu H. Umar K. Ahmad, S.Ag, peningkatan mutu guru, bahwa beliau berkomentar:

Sebenarnya mutu guru di Madrasah Aliyah Negeri 1 Kota Gorontalo ini sudah bagus dibandingkan dengan Madrasah lainnya di Lingkungan Kota Gorotalo, tapi juga perlu ditingkatkan lagi tentunya, dan saya amati Sepak terjang atau Strategi Madrasah Aliyah Negeri 1 Kota Gorontalo juga sudah bagus dalam menjalankan tugasnya dalam peningkaatan mutu guru di Madrasah Aliyah Negeri 1 Kota Gorontalo, sehingga saya yakin dengan Strategi yang dilakukan bapak kepala Madrasah Aliyah Negeri 1 Kota Gorontalo ke depannya mutu guru di Madrasah Aliyah Negeri 1 Kota Gorontalo lebih baik lagi dari yang sebelumnya. ${ }^{26}$

Program Madrasah disusun berdasarkan hasil musyawarah seluruh personel guru pada setiap awal tahun pelajaran. Hasil evaluasi program yang belum tuntas, dijadikan sebagai program lanjutan dalam penyususnan program baru. Program peningkatan mutu didokumentasikan dalam program tahunan dan program semester untuk dijadikan sebagai pedoman dalam melaksanakan program sesuai dengan kesepakatan bersama. Setiap madrasah mesti melakukan kegiatan perencanaan untuk menyelenggarakan program madrasah dan jika madrasah itu ingin mencapai yang terbaik, maka madrasah itu harus menggunakan rencana strategis.

\section{Kendala dalam Peningkatkan Mutu guru pada Madrasah Aliyah Negeri 1 Kota Gorontalo}

Dalam observasi yang peniliti lakukan di Madrasah Aliyah Negeri 1 Kota Gorontalo menemukan beberapa kendala kepala Madrasah dalam meningkatkan mutu guru di Madrasah Aliyah Negeri 1 Kota Gorontalo, yakni sebagai berikut:

Kendala yang dihadapi dalam peningkatan mutu guru di Madrasah Aliyah

Negeri 1 Kota Gorontalo, cukup banyak juga, diantaranya adalah kemampuan

${ }^{26}$ H. Umar K. Ahmad, S.Ag, Komite Madrasah Aliyah Negeri 1 Kota Gorontalo, wawancara, Tanggal 20 November 2019 


\section{Irfani}

ISSN 1907-0969 E ISSN 2442-8272

Volume 15 Nomor 2 Desember 2019

Halaman 59-75

http://journal.iaingorontalo.ac.id/index.php/ir

guru di Madrasah Aliyah Negeri 1 Kota Gorontalo tidak sama dalam pengetahuan tentang teknologi, latar belakang guru tidak sama, karakter guru juga berbeda, lulusannya dari perguruan tingg yang berbeda, sehingga dalam pelaksanaan peningkatan guru di Madrasah Aliyah Negeri 1 Kota Gorontalo juga berpengaruh, tentang kedisiplinan guru sebagian ada yang kurang karena jarak tempuh tempat kerja dengan rumahnya jauh. Semua ini akan mempengaruhi pelaksanaan mutu guru di di Madrasah Aliyah Negeri 1 Kota Gorontalo $^{27}$

Dalam peningkatan mutu guru ini tentunya kepala madrasah pasti mengalami kendala-kendala atau hambatan yang dihadapinya. Buktinya dalam wawancara tersebut pada hari senin ,tanggal 25 November 2019 Kepala Madrasah juga mengatakan kepada penulis bahwa ;

Kendala yang dihadapi kepala madrasah dalam meningkatkan mutu guru pada Madrasah Aliyah Negeri 1 Kota Gorontalo adalah kedisiplinan guru masih kurang, sebagian personel madrasah kurang komitmen dalam menjalankan program peningkatan mutu, guru kurang tepat waktu dalam melaksanakan kegiatan belajar mengajar, sebagian guru kurang persiapan dalam mengajar karena tidak semua guru lengkap administrasinya, yang lengkap kurang lebih 70\% dari total jumlah guru di Madrasah Aliyah Negeri 1 Kota Gorontalo, yang lengkap administrasi perangkatnya 30\% dari jumlah guru. Ketika saya meneliti pada waktu minta tandatangan saya dalam menghadapi akreditasi maupun ketika diperiksa pengawas 28

Dalam hal ini saya (Kepala Madrasah) memberikan saran dan masukan ataupun pembinaan setelah kejadian tersebut, akhirnya hamper semua guru di Madrasah Aliyah Negeri 1 Kota Gorontalo membuat adminisatrasi KBMnya lengkap hanya sebagian yang kurang sedikit tetapi sudah mengalami kemajuan yang pesat. Disamping itu saya galakkan bagi guru yang sudah sertifikasi supaya membeli laptop semuanya untuk peningkatan mutu guru di Madrasah Aliyah Negeri 1 Kota Gorontalo. Alhamdulillah semua guru saya amati sudah punya laptop sendiri-sendiri, tetapi kendalanya juga ada yaitu, yang mahir dalam menggunakan Laptop hanya sedikit yakni 10 guru sedang yang lainnya juga sudah bisa semua dalam tahapan belajar, karena semua guru harus bisa mengupdate datanya masing-masing untuk kendala yang ada dalam lingkungan guru Madrasah Aliyah Negeri 1 Kota Gorontalo dapat terselesaikan dengan bertahap demi tahap sampaiu sekarang udah hamper

\footnotetext{
${ }^{27}$ Dr. H. Waris Masuara, S.Ag, M.H.I Kepala Madrasah Aliyah Negeri 1 Kota Gorontalo, wawanara, Tanggal 25 November 2019

${ }^{28}$ Dr. H. Waris Masuara, S.Ag, M.H.I Kepala Madrasah Aliyah Negeri 1 Kota Gorontalo, wawanara, Tanggal 25 November 2019
} 


\section{Irfani}

ISSN 1907-0969 E ISSN 2442-8272

Volume 15 Nomor 2 Desember 2019

Halaman 59-75

http://journal.iaingorontalo.ac.id/index.php/ir

keseluruhan mutu guru di Madrasah Aliyah Negeri 1 Kota Gorontalo bisa meningkat semua berkat kerjasamnya saya selaku Kepala Madrasah dengan komite, masyarakat dan para guru ataupun staf karyawan ${ }^{29}$

\section{Solusi dari Kepala Madrasah dalam Meningkatkan Mutu Guru di Madrasah Aliyah Negeri 1 Kota Gorontalo}

Dalam konteks ini, Kepala Madrasah Aliyah Negeri 1 Kota Gorontalo perlu pendekatan khusus kepada guru-guru yang menjadi kendala dalam pelaksanan peningkatan mutu guru, agar para guru di di Madrasah Aliyah Negeri 1 Kota Gorontalo dapat meningkatkan mutu secara bersama-sama dan selalu loyal pada ketertiban yang dibuat bersama dan yang telah direncanakan oleh kepala madrasah. Untuk ini kepala di Madrasah Aliyah Negeri 1 Kota Gorontalo harus dapat memberikan contoh dan selalu memberikan motivasi kepada seluruh guru di Madrasah Aliyah Negeri 1 Kota Gorontalo, supaya lebih meningkatkan lagi mutu guru tersebut. Dalam hal ini Kepala di Madrasah Aliyah Negeri 1 Kota Gorontalo selalu mengadakan evaluasi diri (supervisi ) kepada para guru-guru di di Madrasah Aliyah Negeri 1 Kota Gorontalo setiap semester, bahkan kalau perlu setiap 1 bulan sekali, agar para guru mau membenahi diri masing-masing. Untuk mengatasi kendala (solusi) tersebut Kepala di Madrasah Aliyah Negeri 1 Kota Gorontalo setiap ada kesempatan waktu kosong selalu mengadakan pembinaan, mengikutsertakan guru-guru untuk mengembangkan diri mengikuti Diklat, Seminar, Workshop, dan yang lainnya yang mendukung dalam peningkatan mutu guru tersebut. Kepala di Madrasah Aliyah Negeri 1 Kota Gorontalo menyarankan agar guru tepat waktu, dalam mengajar hendaklah selalu berangkat lebih pagi lagi bagi guru yang rumahnya jauh atau mengontrak rumah yang dekat dengan madrasahan. Bagi guru yang kurang kemampuan dalam ilmu teknologinya agar mau belajar atau kursus komputer, dan mengikuti pelatihan pelatihan atau diklat atau belajar dengan teman guru yang pandai dalam bidang teknologi. Dalam hal ini Kepala Madrasah juga mengadakan pendidikan dan pelatihan sendiri di lingkungan di Madrasah Aliyah Negeri 1 Kota Gorontalo untuk guru-guru. Dalam rangka peningkatan mutu guru dan menemukan solusi yang dihadapi guru di Madrasah Aliyah Negeri 1 Kota Gorontalo tersebut.

\section{KESIMPULAN}

Berdasarkan hasil penelitian dan pembahasan yang telah peneliti lakukan, tentang Strategi Kepemimpinan Dalam Meningkatkan Mutu Pembelajaran Guru di Madrasah Aliyah Negeri 1 Kota Gorontalo Tahun Pelajaran

29 Dr. H. Waris Masuara, S.Ag, M.H.I Kepala Madrasah Aliyah Negeri 1 Kota Gorontalo, wawanara, Tanggal 25 November 2019 


\section{Irfani}

ISSN 1907-0969 E ISSN 2442-8272

Volume 15 Nomor 2 Desember 2019

Halaman 59-75

http://journal.iaingorontalo.ac.id/index.php/ir

2019/2020, maka peneliti dapat menarik kesimpulan sesuai dengan keadaan di lapangan adalah sebagai berikut: Strategi yang diterapkan pada peningkatan mutu guru dalam pembelajaran di Madrasah Aliyah Negeri 1 Kota Gorontalo, yaitu (1) menyelenggarakan penataran (workshop) madrasah. Kepala madrasah mewajibkan untuk seluruh guru mengikuti workshop agar dapat meningkatkan keterampilan dan mengasah pengetahuan guru. Selain itu ilmu yang disampaikan pada peserta didik tidak terkesan monoton. (2) memberikan kesempatan kepada guru untuk meningkatkan pendidikannya melanjutkan ke S2. Hal tersebut disebabkan oleh jumlah guru yang pendidikannya S2 di Madrasah Aliyah Negeri 1 Kota Gorontalo masih dapat dikategorikan sedikit. (3) meningkatkan sikap profesionalisme guru, yaitu kepala madrasah menyarankan agar guru selalu rajin membaca, belajar dan berdiskusi dengan guru-guru yang lain sesuai mapel masing-masing. Kendala yang dihadapi dalam peningkatan mutu guru di Madrasah Aliyah Negeri 1 Kota Gorontalo, cukup banyak juga, diantaranya adalah kemampuan guru di Madrasah Aliyah Negeri 1 Kota Gorontalo tidak sama dalam pengetahuan tentang teknologi, latar belakang guru tidak sama, karakter guru juga berbeda, lulusannya dari perguruan tingg yang berbeda, sehingga dalam pelaksanaan peningkatan guru di Madrasah Aliyah Negeri 1 Kota Gorontalo juga berpengaruh, tentang kedisiplinan guru sebagian ada yang kurang karena jarak tempuh tempat kerja dengan rumahnya jauh. Semua ini akan mempengaruhi pelaksanaan mutu guru di di Madrasah Aliyah Negeri 1 Kota Gorontalo. Adapun solusi dalam peningkatan mutu pembelajaran di Madrasah Aliyah Negeri 1 Kota Gorontalo, yaitu dengan diadakannya beberapa kegiatan-kegiatan di SMA Negeri 1 Dompu, melalui kegiatan-kegiatan ini Kepala Madrasah dapat meningkatkan mutu pendidikan agama Islam dengan implementasi strategi yang tepat dan sesuai dengan sekolah. Selain itu, kepala Madrasah selalu mengirimkan peserta guru untuk mengikuti pendidikan dan pelatihan/workshop dan Kepala sekolah selalu memberikan pembinaan dan arahan untuk melanjutkan pendidikan lagi ke S2.

\section{DAFTAR PUSTAKA}

Hadijaya, Usuf. Menyusun Strategi Berbuah Kinerja Pendidik Efektif, Medan: Perdana Publishing,2013.

Komari Aan, Cepi Triana, Visioneriy leadership Menuju Sekolah Efektif, Jakarta: Bumi Aksara, 2006.

Kuncoro, Mudrajad. Strategi Bagaimana Meraih Keunggulan Kompetitif, Jakarta: Erlangga, 2016.

Marno dan Triyo Supriyanto, Manajemen dan Kepemimpinan Pendidikan Islam, Bandung: PT Refika Aditama, 2008. 


\section{Irfani}

ISSN 1907-0969 E ISSN 2442-8272

Volume 15 Nomor 2 Desember 2019

Halaman 59-75

http://journal.iaingorontalo.ac.id/index.php/ir

Rochaety, Eti dkk, Sistem Informasi Manajemen, Jakarta: Bumi Aksara, 2010. 27

Syafaruddin dan Asrul, Kepemimpinan Pendidikan Kontemporer, Bandung: Citapustaka Media, 2015.

Sudaryono, Dasar-Dasar Evaluasi Pembelajaran, Yogyakarta: Graha Ilmu, 2012. Siagian, Sondang P. Manjemen Strategi, Jakarta: Bumi Aksara, 2004. 